\title{
SERUM 25-HYDROXYVITAMIN D CONCENTRATIONS AND SELECTED DIET COMPONENTS IN POSTMENOPAUSAL WOMEN
}

\author{
Anna Huta-Osiecka ${ }^{1 凶}$, Zbigniew Kasprzak ${ }^{1}$, Krystian Wochna ${ }^{2}$, Alicja Nowak ${ }^{1}$ \\ ${ }^{1}$ Department of Hygiene, Poznań University of Physical Education \\ Królowej Jadwigi 27/39, 61-871 Poznań, Poland \\ ${ }^{2}$ Department of Swimming and Water Lifesaving, Poznań University of Physical Education \\ Królowej Jadwigi 27/39, 61-871 Poznań, Poland
}

\begin{abstract}
Objective. Nutrition and lifestyle factors play an important role in the development and maintenance of peak bone mass and the prevention of bone degradation. The aim of the present study was to assess 25-hydroxycholecalciferol $[25(\mathrm{OH}) \mathrm{D}]$ serum concentration in postmenopausal women during the winter period and the supply of selected components in their diet.

Material and methods. The study was conducted on a group of 35 women aged 54-77, using a questionnaire, including a 24-hour recall related to a subject's nutrient consumption. Serum concentrations of $25(\mathrm{OH})$ $\mathrm{D}$ were determined. Body composition was assessed with bioelectrical impedance analysis.

Results. Mean 25(OH)D serum concentration was found to be $61.2 \%$ of the minimum healthy level, according to the reference values. The supply of vitamin D and calcium covered $36.2 \%$ and $56.7 \%$ of RDA respectively. Correlation analysis has shown a significant inverse relationship between $25(\mathrm{OH}) \mathrm{D}$ serum concentration and body fat $(p<0.05)$.

Conclusions. The study indicates a decreased serum concentration of $25(\mathrm{OH}) \mathrm{D}$ in postmenopausal women during the winter period and a low supply of vitamin D and calcium in their diet. Nutrition education should be introduced to the adult population to prevent bone fractures.
\end{abstract}

Keywords: women, menopause, nutrition, 25(OH)D

\section{INTRODUCTION}

Bone loss in postmenopausal women is a consequence of increased bone metabolism rate, which is associated to a large extent with hormonal changes (Seeman, 2013). However, a complex interaction of different factors, including genetic and lifestyle factors, also play an important role (Curtis et al., 2015). Of key importance in osteoporosis prevention is attaining peak bone mass in childhood and early adolescence by maintaining a high level of physical activity and appropriate diet, including sources of calcium and vitamin D (Bonjour et al., 2014). In later stages of life, appropriate nutrition and physical activity can slow down the rate of bone degradation. Some authors have demonstrated that supplementation with calcium and vitamin D reduces postmenopausal or age-related decrease in bone mass and the risk of bone fractures (Knapik et al., 2017).

Studies conducted on the Polish population have shown that $70 \%$ of subjects have a vitamin D deficiency, measured by serum calcidiol $(25(\mathrm{OH}) \mathrm{D})$ concentration. Serum $25(\mathrm{OH}) \mathrm{D}$ assay is considered to be the best indicator of adequate vitamin $\mathrm{D}$ supply. It provides 
information about the availability of the substrate for local synthesis of biologically active calcitriol. The most important source of vitamin $\mathrm{D}$ is synthesis in the skin, induced by sun exposure (Mostafa and Hegazy, 2015). Very few foods naturally contain vitamin D (Holick and Chen, 2008; Płudowski et al., 2013). Some of the factors that are responsible for vitamin D deficiency include decreased synthesis in the skin, related to geographical latitude, especially in the autumn-winter period, and lack of exposure to ultraviolet B (UVB) radiation as a result of lifestyle changes. Several studies have reported that obese subjects have an increased risk of vitamin $\mathrm{D}$ deficiency. There is evidence that vitamin D metabolism, storage and action are influenced by adiposity (Vimaleswaran et al., 2013).

Nutritional factors that play an important role in the development and maintenance of normal bone structure, other than vitamin D and calcium, are micronutrients such as phosphorus, magnesium, zinc, copper, potassium and vitamins: A, $\mathrm{K}_{2}, \mathrm{C}$ and $\mathrm{E}$ (Holick and Chen, 2008; Prentice et al., 2006; Torbergsen et al., 2017). Another important element in the diet is protein. However, excessive consumption of protein, especially animal protein, may have an adverse effect on bone tissue metabolism (Sellmeyer et al., 2011). The supply of the above-mentioned nutrients not only ensures appropriate mechanical strength of bones, but also reduces the risk of falls, especially in the elderly population, through its effect on the musculoskeletal and nervous systems (Curtis et al., 2015).

The aim of the present paper is to assess serum concentration of $25(\mathrm{OH}) \mathrm{D}$ and the dietary supply of selected micro- and macronutrients important for adequate bone tissue metabolism in postmenopausal women during the winter period.

\section{MATERIALS AND METHODS}

The study was conducted on a group of 35 postmenopausal women aged 54 to 77 living in Poland. Only subjects who declared themselves to be in good health were enrolled; women with inflammatory disorders, diabetes mellitus or hormonal disturbances were not included in the study. Before the beginning of the study, all subjects were informed about the purpose and methods of conducting the study. All subjects expressed their voluntary consent to participate in the study.
The study protocol was approved by the Ethics Committee for Human Research at the Poznań University of Medical Sciences. The nutritional status of the women was assessed with a 24-hour dietary recall (Charzewska et al., 1997). The interview was conducted for three days (two working days and one holiday). Energy value and nutritional value of dietary intakes were calculated using the "Dietetyk" software developed by JuMar (Poland). When determining the degree of adherence to dietary recommendations, we used the guidelines of the National Food and Nutrition Institute in Warsaw (Jarosz, 2012). Only 5 women participating in the study declared using vitamin D supplementation for a period of 3 to 6 months in the winter period. During the study period, 22 of the subjects exercised for at least 90 minutes per week.

Somatic traits (weight and height) of the women studied were measured and their body mass index (BMI) was calculated. Weight and height were measured using a certified Radwag device (Radom, Poland) with an accuracy of $0.01 \mathrm{~kg}$ and $0.5 \mathrm{~cm}$ respectively (Table 1). The body composition of the women was assessed using bioelectrical impedance analysis (BIA) and a TANITA PC-418 MA device.

The somatic traits, calorie intake and the amount of basic macro- and micronutrients in the daily intake of food were presented in the form of an arithmetic mean, standard deviation, median and quartiles (Table 1). The intake of vitamins and minerals was compared to the Recommended Dietary Allowances (RDA) and Estimated Average Requirement (EAR) endorsed by the National Food and Nutrition Institute for the Polish

Table 1. Basic characteristics and serum 25(OH)D concentration of women participating in the study

\begin{tabular}{lcc}
\hline & $\mathrm{x} \pm \mathrm{SD}$ & $\mathrm{Me}(\mathrm{Q} 1-\mathrm{Q} 3)$ \\
\hline Age, years & $62.4 \pm 4.80$ & $62.0(60.0-65.6)$ \\
Height, cm & $160.0 \pm 4.90$ & $159.0(157.0-164.5)$ \\
Body mass, kg & $67.3 \pm 11.51$ & $65.1(62.1-71.0)$ \\
BMI, kg/m ${ }^{2}$ & $26.3 \pm 4.34$ & $25.4(24.0-26.9)$ \\
Fat mass, kg & $26.1 \pm 8.24$ & $24.4(21.1-28.7)$ \\
Fat mass, \% & $38.1 \pm 6.18$ & $38.4(33.8-42.5)$ \\
$25(\mathrm{OH}) \mathrm{D}, \mathrm{ng} / \mathrm{ml}$ & $18.8 \pm 9.73$ & $18.0(11.6-23.9)$ \\
\hline
\end{tabular}


female population in the relevant age range; for sodium, potassium and vitamin $\mathrm{E}$, the average intake of these elements was compared to Adequate Intake (IA) values recommended by the Institute (Jarosz, 2012).

Fasting blood samples for biochemical assays were collected at the end of winter (March) from the ulnar vein, between 8 and 10 o'clock in the morning, and were subsequently centrifuged to obtain serum. Blood serum was stored in $-70^{\circ} \mathrm{C}$ awaiting biochemical analysis. Serum concentrations of 25-hydroxycholecalciferol $[25(\mathrm{OH}) \mathrm{D}]$ were determined with the immunoenzymatic enzyme-linked immunosorbent assay (ELISA) method (the kit of Demeditec Diagnostic $\mathrm{GmbH}$, Germany; sensitivity $1.9 \mathrm{ng} / \mathrm{ml}$ ) and chemiluminescence immuno assays (CLIA) (LIAISON® 25 OH Vitamin D TOTAL Assay, DiaSorin Inc., USA, sensitivity $4 \mathrm{ng} / \mathrm{ml}$ ).

Normality of $25(\mathrm{OH}) \mathrm{D}$ distribution was measured using the Shapiro-Wilk test, and homogeneity of variance was assessed with Levene's test. Correlation analysis for variables with normal distribution was conducted using Pearson's correlation coefficient. For variables with a non-normal distribution, the
Spearman's rank correlation coefficient was used. The threshold of $p<0.05$ was chosen as a critical level of significance. Statistical calculations were performed with the STATISTICA 12.5 PL software.

\section{RESULTS}

Table 1 presents the basic characteristics of the women participating in the study and their serum $25(\mathrm{OH}) \mathrm{D}$ concentrations. Although the mean BMI indicated was slightly overweight, $43 \%$ of women had normal body weight (BMI $<25 \mathrm{~kg} / \mathrm{m}^{2}$ ). The average concentration of $25(\mathrm{OH}) \mathrm{D}$ in blood serum was found to be $61.2 \%$ of the minimum healthy level (Holick and Chen 2008; Płudowski et al., 2013). Optimal concentration of 25(OH)D ( $\geq 30 \mathrm{ng} / \mathrm{ml})$ was found only in six subjects, two of whom took vitamin $\mathrm{D}$ in the form of dietary supplements. An adequate supply of vitamin D in the diet, according to guideline levels, was found in one subject (Jarosz, 2012).

Table 2 presents descriptive statistics of calorie intake and selected macro- and micronutrients in the diet. The percentage of energy derived from protein

Table 2. Nutritional characteristics of diet

\begin{tabular}{lccc}
\hline & $\mathrm{x} \pm \mathrm{SD}$ & $\mathrm{Me}(\mathrm{Q} 1-\mathrm{Q} 3)$ & \% RDA/\% AI* \\
\hline Daily energy intake, kcal/day & $1809.91 \pm 407.67$ & $1704.5(1503.4-2046.5)$ & - \\
Protein total, g/day & $73.2 \pm 15.05$ & $71.8(65.3-77.6)$ & - \\
Protein animals, g/day & $49.13 \pm 14.50$ & $46.6(41.2-54.1)$ & - \\
Protein vegetable, g/day & $24.0 \pm 7.23$ & $24.9(18.3-28.2)$ & 56.7 \\
Calcium, mg/day & $680.5 \pm 206.60$ & $646.4(549.1-784.8)$ & 97.0 \\
Magnesium, mg/day & $310.5 \pm 73.19$ & $301.0(251.5-33.4)$ & 177.37 \\
Phosphorum, mg/day & $1241.6 \pm 235.63$ & $1241.6(1108.0-1339.2)$ & $145.0^{*}$ \\
Sodium, mg/day & $2001.1 \pm 749.24$ & $1779.6(1516.0-2266.3)$ & $66.2^{*}$ \\
Potasium, mg/day & $3114.3 \pm 1073.3$ & $3219.1(2781.0-3529.8)$ & 126.1 \\
Zn, mg/day & $10.01 \pm 1.94$ & $10.0(8.9-11.1)$ & 36.1 \\
Vitamin D, $\mu \mathrm{g}$ /day & $5.5 \pm 7.80$ & $3.1(2.1-6.4)$ & 172.7 \\
Vitamin C, mg/day & $129.5 \pm 70.33$ & $113.5(77.9-164.2)$ & 240.2 \\
Vitamin A, $\mu \mathrm{g}$ /day & $1681.9 \pm 1962.64$ & $1192.7(917.8-1543.4)$ & $130.6^{*}$ \\
Vitamin E, mg/day & $10.5 \pm 4.17$ & $10.6(8.7-12.2)$ & \\
\hline
\end{tabular}

*\% $\mathrm{AI}$ - adequate intake, RDA - recommended dietary allowances. 
was $16.6 \%$. Having calculated the supply of protein calculated per $1 \mathrm{~kg}$ of body mass, we obtained a mean protein intake of $1.1 \pm 0.2 \mathrm{~g} / \mathrm{kg}$, which only slightly exceeded the recommended level (i.e. $0.8 \mathrm{~g} / \mathrm{kg}$ of body mass) by Jarosz (2012). However, according to PROTAGE Study Group the protein intake was compatible with their recommendations for older people (1.0-1.2 $\mathrm{g} / \mathrm{kg}$ of body mass; Bauer et al., 2013). The ratio of animal to plant protein was $2: 1$ on average $(67 \%$ animal protein).

Adherence to the recommended daily intake levels for vitamins and mineral nutrients is presented as percentage of reference intakes endorsed by the National Food and Nutrition Institute for a population of women in the relevant age group. The mean supply of calcium was $31.9 \%$ lower than the EAR for women over 50 years of age, while the supply of phosphorus exceeded the EAR by $114.1 \%$. The ratio of calcium to phosphorus in the diet of the subjects was 1:1.82 on average. Consumption of zinc and magnesium exceeded the EAR by $4.4 \%$ and $17.2 \%$ levels respectively. With regard to the supply of vitamin D, only $55.1 \%$ of the EAR was met, whereas supply of vitamin A and $C$ exceeded the EAR considerably $(236.4 \%$ and $115.9 \%$, respectively).

Correlation analysis demonstrated a significant inverse relationship between the serum $25(\mathrm{OH}) \mathrm{D}$ concentration and body fat expressed in kilograms $(R=$ $-0.35 ; p=0.041)$. However, there was no significant association between $25(\mathrm{OH}) \mathrm{D}$ concentration and the amount of vitamin $\mathrm{D}$ in the diet $(p=0.199)$.

\section{DISCUSSION}

The most important finding of the study is low serum concentration of $25(\mathrm{OH}) \mathrm{D}$ and the inverse relationship of this parameter with body fat. However, the main limitation of the study is the small number of participants. Moreover, the application of other biochemical indices expressing vitamin D metabolism and more precise methods of measurement of body composition could improve the findings of the research.

According to expert recommendations, the optimal concentration of $25(\mathrm{OH}) \mathrm{D}$ should exceed $30 \mathrm{ng} / \mathrm{ml}$ (Holick et al., 2012; Płudowski et al., 2013). A concentration of $20 \mathrm{ng} / \mathrm{ml}$ does not ensure optimal calcium metabolism and bone health in all individuals
(Holick et al., 2005). Only in 17\% of the subjects did the concentration of $25(\mathrm{OH}) \mathrm{D}$ exceeded $30 \mathrm{ng} / \mathrm{ml}$, whereas in $43 \%$ of the women the level of $25(\mathrm{OH}) \mathrm{D}$ was suboptimal $(20-30 \mathrm{ng} / \mathrm{ml})$. This may be explained by low exposure to UVB radiation during the study period (winter) and the limited supply of vitamin D in the diet of the study subjects. According to the Polish guidelines, the optimal daily intake of vitamin D for the adult population aged 51-70 years should be $15 \mu \mathrm{g}$, and for the population aged $>70$ years $-20 \mu \mathrm{g}$ (Jarosz, 2012). Only one woman in our study gained the recommended amount of vitamin D from her diet. However, we did not find any association between concentration of $25(\mathrm{OH}) \mathrm{D}$ in blood serum and supply of vitamin D in the diet. Cashman et al. (2017) suggested that the vitamin $\mathrm{D}$ intake required to prevent $25(\mathrm{OH}) \mathrm{D}$ inadequacy $(<50 \mathrm{nmol} / \mathrm{L} ; 20 \mathrm{ng} / \mathrm{ml})$ in $97.5 \%$ of the population (age from 4 to 90 years) is 26 $\mu \mathrm{g} /$ day. Many food products contain small amounts of this vitamin. The most abundant natural source of vitamin $\mathrm{D}_{3}$ (cholecalciferol) is fish (Jungert et al., 2014). Studies conducted on a population of elderly Japanese women have shown that increased fish consumption was positively correlated with serum $25(\mathrm{OH}) \mathrm{D}$ concentration (Nakamura et al., 2000). The lower concentration of $25(\mathrm{OH}) \mathrm{D}$ in the blood serum of the participants may also be attributed to absorption disorders, which decrease bioavailability of vitamin $\mathrm{D}$ from the gastrointestinal tract, and to obesity, as the mechanism of using vitamin $\mathrm{D}$ stored in adipose tissue may be disturbed (Holick and Chen, 2008). This may also be confirmed by the inverse association between the concentration of 25(OH)D and amount of body fat observed in the present study. Our results are in line with studies by other authors (Vimaleswaran et al., 2013; Wortsman et al., 2000). Al-Eisa et al. (2016) demonstrated that serum $25(\mathrm{OH}) \mathrm{D}$ levels were negatively correlated with BMI and hip and waist circumference in the elderly population. The authors suggest that lower levels of serum $25(\mathrm{OH}) \mathrm{D}$ in obese subjects may be related to sequestration in fat or lower rates of lipolysis in obese subjects. However, a clear association between vitamin D status and obesity and/or metabolic dysfunction has been discussed (Cordeiro et al., 2017).

Vitamin D effects the regulation of calcium absorption from the gastrointestinal tract and the mineralization of the bone matrix. The supply of vitamin D is 
important due to its calciotropic properties, as well as its role in regulating muscle function, maintaining body weight and muscle strength. Vitamin D status correlates positively with muscle strength and postural stability and may be important in fall prevention (Rejnmark, 2011).

Another significant problem in the study group was calcium intake deficiency. Other authors also obtained similar results in the Polish population (Śmidowicz and Reguła, 2015). Given the low vitamin D and calcium intake in many populations, researchers focused on the possibility of fortifying certain products with these nutrients (Whiting et al., 2016). A study carried out on a group of women aged $>60$ years by Bonjour et al. (2015) demonstrated that having two yogurts fortified with calcium $(520 \mathrm{mg})$ and vitamin D $(10 \mu \mathrm{g})$ a day for three consecutive months significantly increased serum concentration of $25(\mathrm{OH}) \mathrm{D}$ and decreased the rate of bone degradation. In a study carried out on postmenopausal women, Bonjour et al. (2008) observed that a 6-week period of milk supplementation diminished bone turnover mediated by reduction in parathyroid hormone secretion. These authors suggested that nutritional intervention may be a valuable measure in the primary prevention of osteoporosis. As well as an optimal supply of calcium in the diet, it is also important to consider the calcium to phosphorus ratio.

The supply of protein in the diet of the women enrolled in the study was higher than the recommended values. A systematic review and meta-analysis from the National Osteoporosis Foundation showed no adverse effects of higher protein intake and positive trends on bone mass at most bone sites (Shams-White et al., 2017). Protein plays a role in the synthesis of collagen and other non-collagen bone proteins. Moreover, it stimulates the production of insulin-like growth factor-1 (IGF-1), which promotes osteoblast-mediated bone formation (Bonjour, 2016). However, it has been suggested that protein derived from vegetable sources may be more beneficial for the bone tissue metabolism than animal protein because of the acid-base balance disturbance (Frassetto et al., 2000). Our studies have demonstrated a high animal to vegetable protein ratio in the women studied, which may have an adverse impact on the acid-base balance of the body (Tylavsky et al., 2008).
As for the dietary micronutrients mediating bone metabolism, we found there was a sufficient supply of vitamin $\mathrm{A}, \mathrm{C}, \mathrm{E}$ and mineral nutrients such as magnesium and zinc. The protective mechanisms of these vitamins on the skeleton have been suggested, such as their ability to reduce oxidative stress and inhibit bone resorption. Moreover, vitamin $\mathrm{C}$ is necessary for the synthesis of collagen (Torbergsen et al., 2017). Torbergsen et al. (2017) in a case-control study have shown that low serum concentrations of vitamin A, C, and $\mathrm{E}$ are associated with an increased risk of hip fracture, possibly through bone turnover mechanisms.

The intake of sodium in our study group markedly exceeded the recommended values. Excess consumption of this element has an adverse influence on calcium metabolism, as sodium plays a role in calcium excretion. Kwon et al. (2017) demonstrated that high sodium intake is associated with lower bone mineral density and a sodium intake of $\geq 2000 \mathrm{mg} /$ day is a risk factor for osteoporosis in postmenopausal women.

In conclusion, our study demonstrates a decreased serum $25(\mathrm{OH}) \mathrm{D}$ concentration during the winter period and low supply of vitamin D and calcium in the diet in a group of postmenopausal women. These nutrients play a significant role in the prevention of osteoporosis, therefore nutrition education should be provided to the adult population.

\section{REFERENCES}

Al-Eisa, E. S., Alghadir, A. H., Gabr, S. A. (2016). Correlation between vitamin $\mathrm{D}$ levels and muscle fatigue risk factors based on physical activity in healthy older adults. Clin. Interv. Aging., 4, 11, 513-522. http://dx.doi. org/10.2147/CIA.S102892

Bauer, J., Biolo, G., Cederholm, T., Cesari, M., Cruz-Jentoft, A. J., Morley, J. E., ..., Boirie, Y. (2013). Evidence-based recommendations for optimal dietary protein intake in older people: a position paper from the PROT-AGE Study Group. JAMDA, 14, 542-559.

Bonjour, J. P., Brandolini-Bunlon, M., Boirie, Y., Morel-Laporte, F., Braesco, V., Bertière, M. C., Souberbielle, J. C. (2008). Inhibition of bone turnover by milk intake in postmenopausal women. Br. J. Nutr., 100(4), 866-874.

Bonjour, J. P., Chevalley, T.(2014). Pubertal timing, bone acquisition, and risk of fracture throughout life. Endocr. Rev., 35(5), 820-847. 
Bonjour, J. P., Benoit, V., Atkin, S., Walrand, S. (2015). Fortification of yogurts with vitamin $\mathrm{D}$ and calcium enhances the inhibition of serum parathyroid hormone and bone resorption markers: a double blind randomized controlled trial in women over 60 living in a community dwelling home. J. Nutr. Health Aging., 19(5), 563-569. http://dx.doi.org/10.1007/s12603-015-0498-8

Bonjour, J. P. (2016). The dietary protein, IGF-I, skeletal health axis. Horm. Mol. Biol. Clin. Investig., 28(1), 3953. http://dx.doi.org/10.1515/hmbci-2016-0003

Cashman, K. D., Ritz, C., Kiely, M. (2017). Odin Collaborators. Improved dietary guidelines for vitamin D: application of individual participant data (IPD)-level metaregression analyses. Nutrients, 9(5), 469. http://dx.doi. org/10.3390/nu9050469

Charzewska, J., Rogalska-Niedźwiedź, M., Jajszczyk, B., Chojnowska, Z., Dubicz, M. (1997). Metody oceny sposobu żywienia na poziomie indywidualnym oraz instrukcja sposobu przeprowadzania wywiadu o spożyciu z ostatnich 24 godzin poprzedzających badanie. Projekt zamawiany: „Studia nad założeniami do polityki wyżywienia w Polsce" [Methods for assessing the individual's diet as well as instructions on how to conduct an intake interview from the last 24 hours preceding the study. Project commissioned: "Studies on assumptions for food policy in Poland"]. Warszawa: Instytut Żywności i Żywienia [in Polish].

Cordeiro, A., Santos, A., Bernardes, M., Ramalho, A., Martins, M. J. (2017). Vitamin D metabolism in human adipose tissue: could it explain low vitamin D status in obesity? Horm. Mol. Biol. Clin. Investig. pii: /j/hmbci. ahead-of-print/hmbci-2017-0003/hmbci-2017-0003. xml. http://dx.doi.org/10.1515/hmbci-2017-0003

Curtis, E., Litwic, A., Cooper, C., Dennison, E. (2015). Determinants of muscle and bone aging. J. Cell Physiol., 230(11), 2618-2625. http://dx.doi.org/10.1002/ jcp.25001

Frassetto, L. A., Todd, K. M., Morris, R. C., Sebastian, A. (2000). Worldwide incidence of hip fracture in elderly women: relation to consumption of animal and vegetable foods. J. Gerontol. A. Biol. Sci. Med. Sci., 55(10), M585-M592.

Holick, M. F., Siris, E. S., Binkley, N., Beard, M. K., Khan, A., Katzer, J. T., ..., de Papp, A. E. (2005). Prevalence of vitamin D inadequacy among postmenopausal North American women receiving osteoporosis therapy. J. Clin. Endocrinol. Metab., 90(6), 3215-3224.

Holick, M. F., Chen, T. C. (2008). Vitamin D deficiency: a worldwide problem with health consequences. Am. J. Clin. Nutr., 87(4), 1080S-1086S.
Holick, M. F., Binkleym, N. C., Bischoff-Ferrari, H. A., Gordon, C. M., Hanley, D. A., Heaney, R. P., ..., Weaver, C. M. (2012). Guidelines for preventing and treating vitamin D deficiency and insufficiency revisited. J. Clin. Endocrinol. Metab., 97(4), 1153-1158. http://dx.doi. org/10.1210/jc.2011-2601

Jarosz, M. (2012). Normy żywienia dla populacji polskiej nowelizacja [Standards of nutrition for the Poland population - amendment]. Warszawa: Instytut Żywności i Żywienia [in Polish]

Jungert, A., Spinneker, A., Nagel, A., Neuhäuser-Berthold, M. (2014). Dietary intake and main food sources of vitamin D as a function of age, sex, vitamin D status, body composition, and income in an elderly German cohort. Food Nutr. Res., 58. http://dx.doi.org/10.3402/fnr. v58.23632

Knapik, J. J, Reynolds, K., Hoedebecke, K. L. (2017). Stress fractures: etiology, epidemiology, diagnosis, treatment, and prevention. J. Spec. Oper. Med., 17(2), 120-130.

Kwon, S. J., Ha, Y. C., Park, Y. (2017). High dietary sodium intake is associated with low bone mass in postmenopausal women: Korea National Health and Nutrition Examination Survey, 2008-2011. Osteop. Int., 28(4),14451452. http://dx.doi.org/10.1007/s00198-017-3904-8

Mostafa, W. Z., Hegazy, R. A. (2015) Vitamin D and the skin: Focus on a complex relationship: A review. J. Adv. Res., 6(6), 793-804. http://dx.doi.org/10.1016/j. jare.2014.01.011

Nakamura, K., Nashimoto, M., Hori, Y., Yamamoto, M. (2000). Serum 25-hydroxyvitamin D concentrations and related dietary factors in peri- and postmenopausal Japanese women. Am. J. Clin. Nutr., 71(5), 1161-1165.

Płudowski, P., Karczmarewicz, E., Bayer, M., Carter G., Chlebna-Sokół, D., Czech-Kowalska, J., ..., Żmijewski, M. A. (2013). Practical guidelines for the supplementation of vitamin D and the treatment of deficits in Central Europe - recommended vitamin D intakes in the general population and groups at risk of vitamin D deficiency. Endokrynol. Pol., 64(4), 319-327.

Prentice, A., Schoenmakers, I., Laskey, M. A., de Bono, S., Ginty, F., Goldberg, G. R. (2006). Nutrition and bone growth and development. Proc. Nutr. Soc., 65(4), 348-360.

Rejnmark, L. (2011). Effects of vitamin d on muscle function and performance: a review of evidence from randomized controlled trials. Ther. Adv. Chronic. Dis., 2(1), 25-37. http://dx.doi.org/10.1177/2040622310381934

Seeman, E. (2013). Age- and menopause-related bone loss compromise cortical and trabecular microstructure. J. Gerontol. A. Biol. Sci. Med. Sci., 68(10), 1218-1225. 
Sellmeyer, D. E., Stone, K. L., Sebastian, A., Cummings, S. R. (2001). A high ratio of dietary animal to vegetable protein increases the rate of bone loss and the risk of fracture in postmenopausal women. Am. J. Clin. Nutr., $73,118-122$.

Shams-White, M. M., Chung, M., Du, M., Fu, Z., Insogna, K. L., Karlsen, M. C., ..., Weaver, C. M. (2017). Dietary protein and bone health: a systematic review and metaanalysis from the National Osteoporosis Foundation. Am. J. Clin. Nutr., 105(6), 1528-1543. http://dx.doi. org/10.3945/ajen.116.145110

Śmidowicz, A., Reguła, J. (2015). Dietary gender differences in terms of the risk of atherogenesis in Poland. Acta Sci. Pol. Technol. Aliment., 14(3), 257-267. http:// dx.doi.org/10.17306/J.AFS.2015.3.37

Torbergsen, A. C., Watne, L. O., Wyller, T. B., Frihagen, F., Strømsøe, K., Bøhmer, T., Mowe, M. (2017). Micronutrients and the risk of hip fracture: Case-control study. Clin. Nutr., 36(2), 438-443. http://dx.doi.org/10.1016/j. clnu.2015.12.014
Tylavsky, F. A., Spence, L. A., Harkness, L. (2008). The importance of calcium, potassium, and acid-base homeostasis in bone health and osteoporosis prevention. J. Nutr., 138, 1645-1655.

Vimaleswaran, K. S., Berry, D. J., Lu, C., Tikkanen, E., Pilz, S., Hiraki, L.T., ..., Ohlsson, C. (2013). Causal relationship between obesity and vitamin D status: bi-directional mendelian randomization analysis of multiple cohorts. PLoS Med., 10. https://doi.org/10.1371/journal. pmed. 1001383

Whiting, S. J., Kohrt, W. M., Warren, M. P., Kraenzlin, M. I., Bonjour, J. P. (2016). Food fortification for bone health in adulthood: a scoping review. Eur. J. Clin. Nutr., 70(10), 1099-1105. http://dx.doi.org/10.1038/ ejen.2016.42

Wortsman, J., Matsuoka, L. Y., Chen, T. C., Lu, Z., Holick, M. F. (2000). Decreased bioavailability of vitamin D in obesity. Am. J. Clin. Nutr., 72(3), 690-693. 